\title{
The Cape Porcupine Complex, northern mainland Nova Scotia - no longer a geological orphan
}

\author{
S. M. BARR ${ }^{1^{*}}$, C. E. WHITE ${ }^{2}$, AND J.W.F. KeTCHUM ${ }^{3}$ \\ 1. Department of Earth and Environmental Science, Acadia University, Wolfville, Nova Scotia B4P 2R6 Canada \\ 2. Nova Scotia Department of Natural Resources, P.O. Box 698, Halifax, Nova Scotia B3J 2T9 Canada \\ 3. Northwest Territories Geoscience Office, PO Box 1500, 4601-B 52 Avenue, Yellowknife, \\ Northwest Territories, X1A 2R3 Canada \\ ${ }^{*}$ Corresponding author <sandra.barr@acadiau.ca $>$
}

Date received: 16 January 2012 gate accepted: 28 April 2012

\begin{abstract}
The Cape Porcupine Complex west of the Strait of Canso in northern mainland Nova Scotia consists of mainly fault-bounded units of metasedimentary, metavolcanic, and granitoid rocks. A previously reported U-Pb (zircon) age of $610 \pm 3 \mathrm{Ma}$ from syenogranite combined with petrological characteristics indicates that some of the granitic rocks and possibly an associated body of leucodiorite are Late Neoproterozoic. In contrast, alkali-feldspar granite from a more extensive suite of quartz alkali-feldspar syenite/alkali-feldspar syenite, alkali-feldspar granite/syenogranite, and quartz alkali-feldspar leucosyenite with A-type characteristics yielded an early Ordovician age of $478 \pm 3 \mathrm{Ma}$. Similar A-type chemical characteristics suggest that the metavolcanic unit may be the extrusive equivalent of the Ordovician suite.

Similarities in age and petrological characteristics indicate that the Cape Porcupine Complex is linked to rock units in the Antigonish Highlands. The ca. 610 Ma granitic rocks are likely related to plutonic and volcanic rocks of similar age in the Antigonish Highlands interpreted to have formed at a continental margin subduction zone. In contrast the A-type syenitic and metavolcanic rocks are probably related to the compositionally similar West Barneys River plutonic suite and younger volcanic rocks formed in an extensional regime. Such rocks do not occur in adjacent Ganderia or Avalonia in Cape Breton Island or southern New Brunswick, further demonstrating the regional significance of the Canso Fault in tectonic reconstructions.
\end{abstract}

\section{RÉSUMÉ}

Situé à louest du détroit de Canso au nord de la partie continentale de la Nouvelle-Écosse, le complexe du cap Porcupine se compose principalement d'unités rocheuses métasédimentaires, métavolcaniques et de granitoïdes limitées par des failles. Une datation réalisée précédemment par la méthode $\mathrm{U}-\mathrm{Pb}$ sur zircon et qui a établi un âge de $610 \pm 3 \mathrm{Ma}$ à partir du syénogranite et des caractéristiques pétrologiques indique qu'une partie des roches de granite et vraisemblablement un corps connexe de leucodiorite sont du Néoprotérozoïque tardif. Par contraste, du granite de feldspath alcalin d'une succession plus importante de syénite de feldspath alcalin quartzeux/syénite de feldspath alcalin, de granite de feldspath alcalin/syénogranite, et de leucosyénite de feldspath alcalin quartzeux présentant des caractéristiques de type $\mathrm{A}$ a produit un âge de l'Ordovicien précoce, soit environ $478 \pm 3 \mathrm{Ma}$. Ces caractéristiques chimiques de type A analogues portent à croire que l'unité métavolcanique pourrait être léquivalent extrusif de la succession de l'Ordovicien.

Les similitudes de datation et les caractéristiques pétrologiques indiquent que le complexe du cap Porcupine est relié aux unités rocheuses des hautes-terres d'Antigonish. Lâge du granite, d'environ $640 \mathrm{Ma}$, se rapporterait vraisemblablement aux roches plutoniques et volcaniques de la même époque observées dans les hautes-terres d'Antigonish, dont on suppose qu'elles ont été formées dans une zone de subduction de la marge continentale. Par contraste, les roches métavolcaniques et syénitiques de type A sont probablement reliées par la similitude de leur composition au cortège plutonique et aux roches volcaniques plus jeunes de la rivière Barneys Ouest formées dans un milieu de distension. Ces roches ne sont pas présentes dans la partie adjacente de Ganderia ou d'Avalonia sur l'île du Cap-Breton ou dans le sud du Nouveau-Brunswick, ce qui tendrait à souligner encore plus l'importance régionale de la faille de Canso dans les reconstructions tectoniques.

[Traduit par la redaction] 


\section{INTRODUCTION}

Porcupine Mountain is a prominent hill adjacent to the Strait of Canso in northern mainland Nova Scotia (Fig. 1). The northeastern part of the hill, marked by a prominent 150 m-high scarp known as Cape Porcupine (Fig. 2), was quarried for the construction of the Canso Causeway in the 1950s, and continues to be a major source of high quality aggregate for local and worldwide markets. Porcupine Mountain consists of varied metasedimentary, metavolcanic, and granitoid rocks which were collectively termed the Cape Porcupine Complex by White and Barr (1998a, b). These rocks form an inlier surrounded by Carboniferous sedimentary rocks (Fig. 2). White et al. (2001, 2003) reported results of mapping, petrological work, and $\mathrm{U}-\mathrm{Pb}$ dating which showed that the Cape Porcupine Complex does not correlate in rock types or age with pre-Carboniferous rocks in adjacent Cape Breton Island. This observation is consistent with its location west of the Canso Fault, interpreted to be a major pre-Carboniferous fault which displaced terranes from New Brunswick about $100 \mathrm{~km}$ to the southeast to Cape Breton
Island (Fig. 1 inset). Less easy to explain at that time was the fact that the rocks of the Cape Porcupine Complex also did not appear to resemble any pre-Carboniferous rocks reported to be present elsewhere in northern mainland Nova Scotia, so the area appeared to be an orphan in terms of regional correlations.

The purpose of this paper is to revisit the geology of the Cape Porcupine Complex in the light of new data emerging from the Antigonish Highlands, where recent mapping has shown the presence of previously unrecognized Ordovician rocks (White and Archibald 2011; White et al. 2011; Escarraga et al. 2012), some of which, as documented here, are petrologically similar to parts of the Cape Porcupine Complex. We also present previously unpublished analytical data for the $\mathrm{U}-\mathrm{Pb}$ (zircon) age reported for a granitic unit by White et al. (2003) and new chemical data for metavolcanic and plutonic units which enable interpretation of their chemical affinity and tectonic setting. Age and petrological similarities now support a link between the Cape Porcupine Complex and units in the Antigonish Highlands.

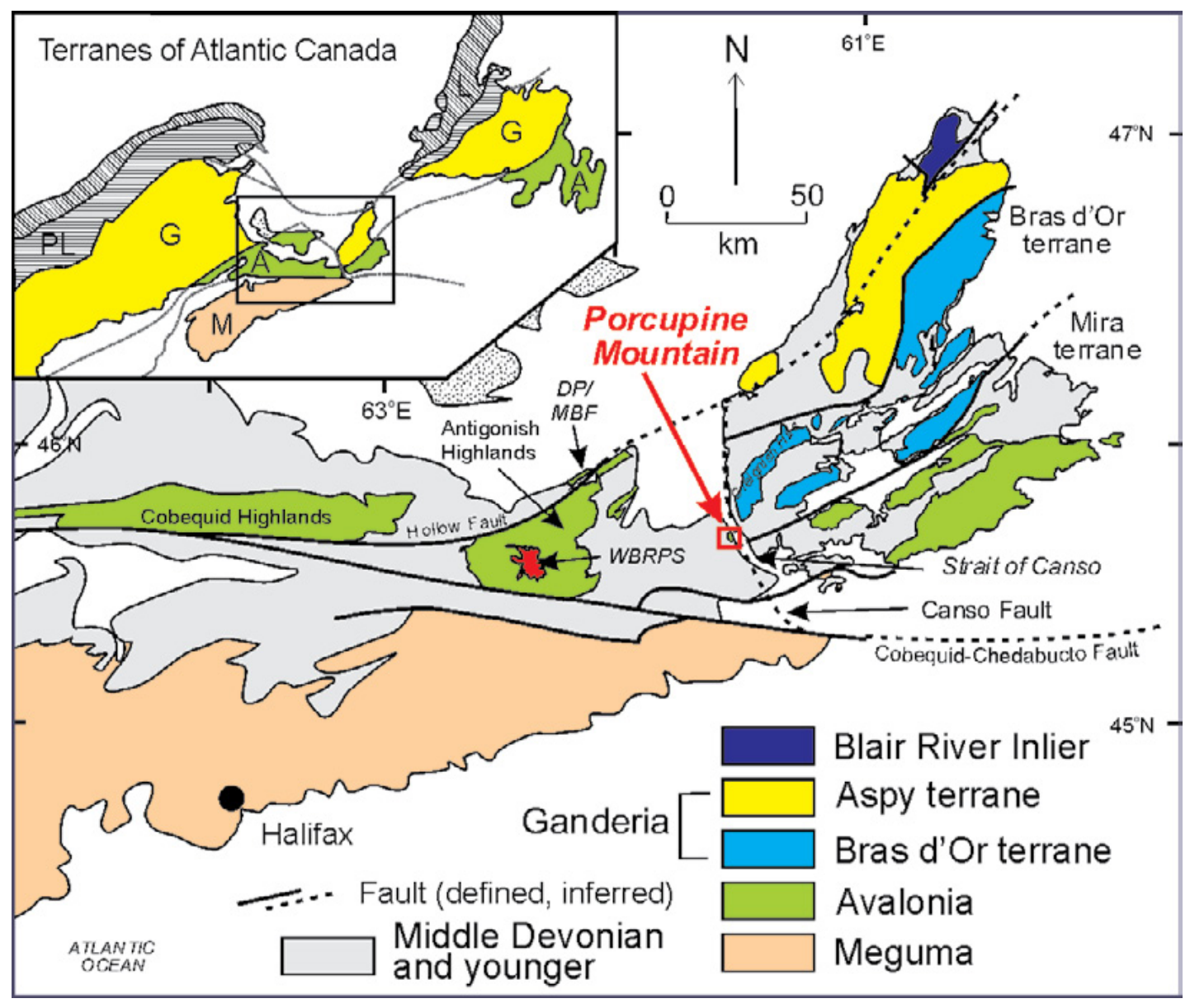

Fig. 1. Simplified geological map of northern Nova Scotia showing the location of Porcupine Mountain (red box). Inset map shows major components of the northern Appalachian orogen after Hibbard et al. (2006). Abbreviations: A, Avalonia; DP/MBF, Dunn Point and McGillivray Brook formations; G, Ganderia; L, Laurentia; M, Meguma; PL, peri-Laurentian terranes; WBRPS, West Barneys River plutonic suite. 


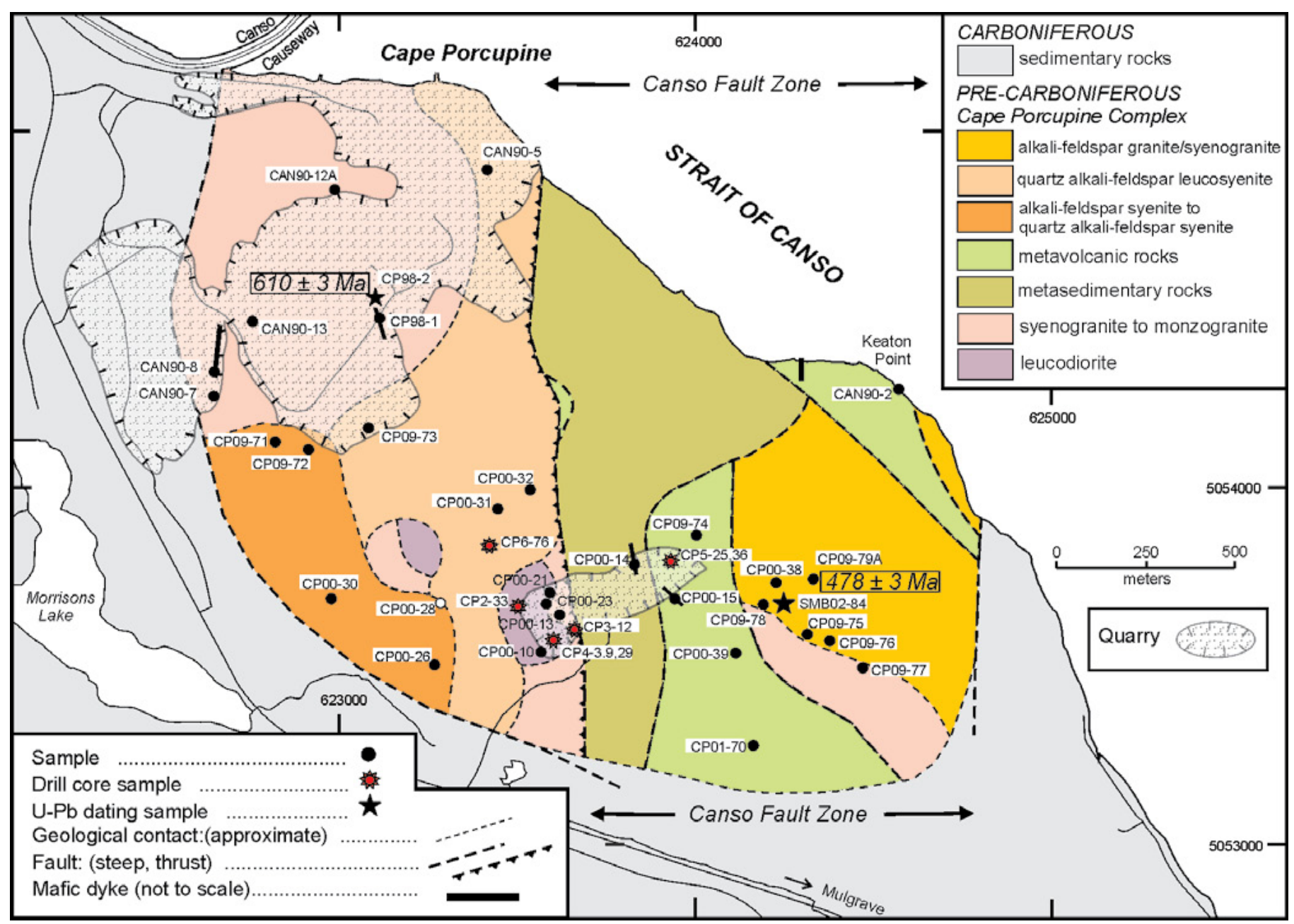

Fig. 2. Geological map of the Cape Porcupine Complex modified after White et al. (2001, 2003). The map area is indicated in Figure 1. Sample locations for analyzed and dated samples are shown. Sample CP00-28 (open symbol) is shown in the photograph in Figure 3e. The Canso Fault Zone marked by arrows indicates the extent of variably mylonitized rocks inferred to be deformed by motion on the Canso Fault.

\section{REGIONAL GEOLOGICAL SETTING}

The Antigonish Highlands of northern mainland Nova Scotia and the Mira terrane of southern Cape Breton Island are both part of Avalonia (Fig. 1), characterized by Neoproterozoic volcanic, sedimentary, and plutonic rocks overlain by Cambrian-Ordovician mainly sedimentary rocks (e.g., Hibbard et al. 2006). However, Avalonia is a composite terrane, and the rocks of the Mira terrane cannot be correlated directly with those of the Antigonish Highlands (Barr et al. 1996). In addition to stratigraphic and age differences in the Neoproterozoic-Cambrian units, the Antigonish Highlands include Ordovician-Devonian volcanic-sedimentary sequences (Murphy et al. 1991, 2008) not present in the Mira terrane. This difference has been further documented during recent mapping and petrological studies in the Antigonish Highlands, which also demonstrated the presence of a large, previously unrecognized Ordovician plutonic suite (Escarraga 2010; White and Archibald 2011; White et al. 2011; Archibald 2012; Escarraga et al. 2012).

In Cape Breton Island, the boundary between Avalonia (Mira terrane) and adjacent Ganderia (Bras d'Or terrane) extends through Bras d'Or Lake to the Strait of Canso where it is offset to the north along the Canso Fault, postulated to follow the western margin of the Creignish Hills (Fig. 1). The orientation of this pre-Carboniferous fault was inferred in part from the presence of mylonitic rocks in the Cape Porcupine Complex (White et al. 2001), located on the western side of the Strait of Canso opposite the inferred termination of the Mira - Bras d'Or terrane boundary (King 2002). 


\section{GEOLOGY OF PORCUPINE MOUNTAIN}

\section{Introduction}

The complexity of rock types on Porcupine Mountain has been known for more than a century. Fletcher (1881, 1884) divided the mountain into a "central slate series" surrounded by "syenite" and "felsite", unconformably overlain by Devonian sedimentary rocks. Ferguson (1946) and Ferguson and Weeks (1950) subdivided the slate series and felsite into an older unit of andesite, chlorite schist, rhyolite, and felsite, intruded by younger granite and alaskite, and overlain by Carboniferous sedimentary rocks of the Horton Group. Graves (1990) further documented the variety of rock types and noted the high degree of epidotization, quartz veining, and cataclasis, as well as the presence of mylonitic rocks.

White et al. $(2001,2003)$ divided the rocks into variably mylonitic metasedimentary, metavolcanic, and varied plutonic units, separated from one another by major faults, and also in faulted contact on the north, east, and west with Carboniferous conglomerate, sandstone, and slate (Fig. 2). On the southern margin of the hill, an unconformable relationship between the older rocks and overlying sedimentary rocks is indicated by the presence of a basal conglomerate that contains abundant clasts derived from the underlying units. A north- to northwest-trending and steeply dipping mylonitic fabric is present throughout the metasedimentary unit and most of the metavolcanic unit, and is locally developed in the plutonic units in the area east of the metavolcanic unit (Fig. 2); sense of motion inferred from asymmetric, subhorizontal porphyroclasts and C-S fabrics is dextral strike-slip (White et al. 2001, 2003). These mylonitic rocks are the only known exposure of the Canso Fault.

\section{Metasedimentary Unit}

Metasedimentary rocks of uncertain age occupy the central area of the Cape Porcupine Complex (Fig. 2). The western contact is a brittle thrust fault dipping to the west. Based on slickenside striations the granitoid rocks appear to be thrust eastward over the metasedimentary rocks. On the east, the metasedimentary rocks are in contact with metavolcanic and granitoid rocks along a near-vertical fault.

The metasedimentary unit consists mainly of grey to black, fine-grained and strongly foliated and lineated metasiltstone, locally with thin $(<0.5 \mathrm{~mm}$ thick), light grey, fine-grained metasandstone lenses. Rare grey, fine-grained quartzite occurs in laterally discontinuous layers, $1-2 \mathrm{~m}$ in thickness. The well developed mylonitic foliation is defined by asymmetric muscovite and chlorite that display uniform crystallographic orientation. The muscovite in two samples yielded ${ }^{40} \mathrm{Ar} /{ }^{39} \mathrm{Ar}$ plateau ages of $364 \pm 2 \mathrm{Ma}$ and $367 \pm 3 \mathrm{Ma}$, an indication of the age of mylonitization and a minimum age for the metasedimentary unit (Reynolds et al. 2004).

\section{Metavolcanic Unit}

The metavolcanic unit forms two separate bodies in the eastern part of Porcupine Mountain, one east of the metasedimentary unit and the other along the Canso Strait in the vicinity of Keaton Point, as well as a small faultbound sliver adjacent to the fault on the western margin of the metasedimentary unit (Fig. 2). In all three areas, the rocks are dominantly grey to dark grey, crystal to crystallithic rhyolitic tuff. Crystals are small $(<3 \mathrm{~mm}$ maximum diameter) and include rounded embayed quartz, subhedral $\mathrm{K}$-feldspar (anorthoclase, based on the presence of finescale cross-hatch twinning), and subhedral plagioclase set in a locally spherulitic groundmass of cryptocrystalline quartz and feldspar. Lithic clasts are generally small $(<1 \mathrm{~cm}$ in diameter), flattened parallel to foliation, and typically consist of rhyolitic tuff. Clasts of andesitic tuff and metasiltstone are rare. Like the metasedimentary rocks, the metavolcanic rocks are strongly foliated and lineated, the latter defined by elongate quartz crystals and lithic clasts. Volcanic layering is typically difficult to recognize because of the strong mylonitic foliation and, where visible, has been transposed parallel to foliation.

Because of structural complexities, the original relationship of the metavolcanic and metasedimentary rocks is uncertain. The presence of rare metasiltsone clasts in the metavolcanic rocks and metavolcanic lenses in the metasiltstone unit suggests that they may have been interlayered originally, although their juxtaposition could also be entirely tectonic. Three attempts to date samples from the meta-rhyolite unit were unsuccessful due to absence of zircon.

\section{Plutonic Rocks}

Varied plutonic rocks form two-thirds of Porcupine Mountain (Fig. 2). Identification of the different varieties is difficult in the field because of their intimate association and widespread cataclastic and/or mylonitic overprints. However, petrographic features enabled division of the plutonic rocks into five units (Fig. 2). The rocks are named based on modal composition estimates from thin section study and slabs stained for K-feldspar (Hutchison 1974), using the terminology of Streckeisen (1976). Typical examples are shown in Figure 3. 

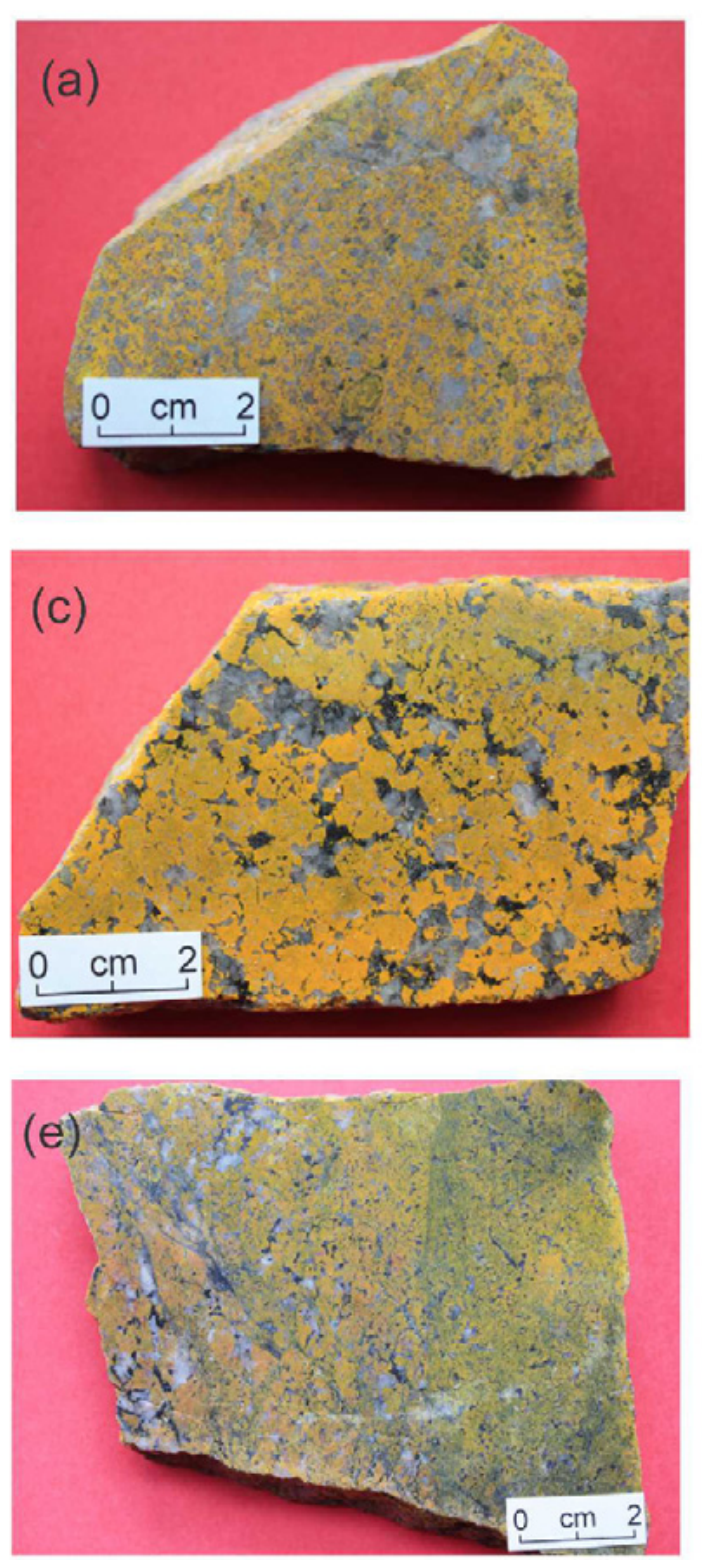
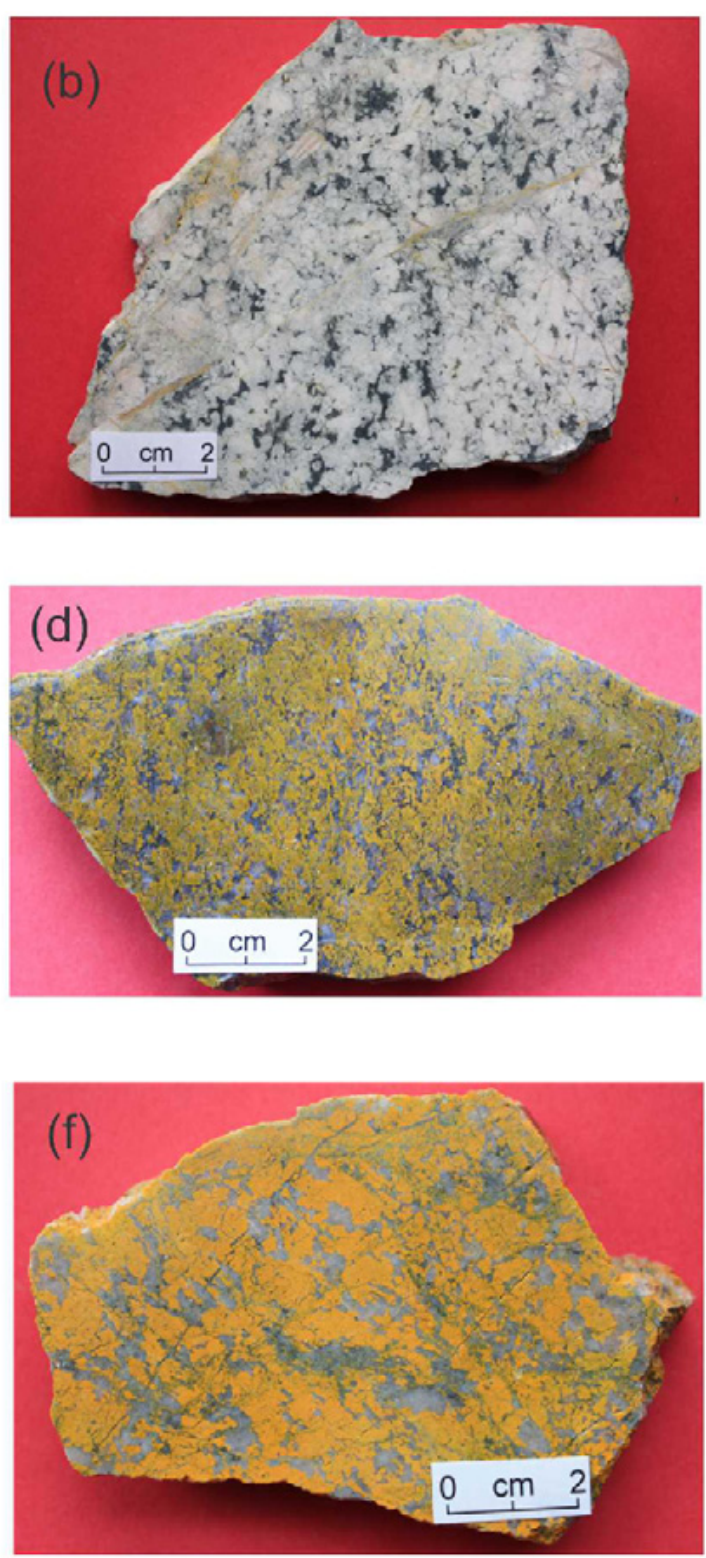

Fig. 3. Photographs of rock slabs from the Cape Porcupine Complex to illustrate main rock types. Slabs have been etched in hydrofluoric acid and stained with sodium cobaltinitrite following the method Hutchison (1974) to enhance textures and highlight K-feldspar (yellow). (a) Quartz porphyritic syenogranite (dated sample CP98-2). (b) Leucodiorite (sample CP00-23). (c) Quartz alkali-feldspar syenite (sample CP09-72). (d) Quartz alkali-feldspar leucosyenite (sample CP09-73). (e) Contact between quartz alkali-feldspar syenite (on left) and fine-grained quartz alkali-feldspar leucosyenite (on right) (sample CP00-28). (f) alkali-feldspar granite (sample CP09-76).

\section{Monzogranite/syenogranite}

Pink to red monzogranite gradational to syenogranite forms the northwestern part of Porcupine Mountain, as well as smaller area in the south and southeast (Fig. 2). Especially in the northwestern areas, where it is well exposed in the main quarry, it is mixed with abundant enclaves of mafic plutonic rocks and metavolcanic rocks of andesitic to rhyolitic composition, and cut by abundant mafic dykes. Texture varies from coarse-grained equigranular to mediumgrained porphyritic, the latter with phenocrysts of quartz and plagioclase up to $1 \mathrm{~cm}$ in length (Fig. 3a). Interstitial granophyre generally is present in syenogranite samples. Mafic minerals may have originally been hornblende and 
biotite, but they have been entirely altered to chlorite and iron oxides. Accessory minerals include zircon, titanite, apatite, and magnetite. White et al. (2001) published a $\mathrm{U}-\mathrm{Pb}$ (zircon) age of $610 \pm 3 \mathrm{Ma}$ from a quartz-porphyritic syenogranite sample typical of the unit.

\section{Leucodiorite}

Leucodiorite forms small areas associated with monzogranite/syenogranite in the southwestern part of the mountain (Fig. 2). The leucodiorite is generally white to light grey, medium- to coarse-grained and inequigranular, and typically consist of a framework of subhedral plagioclase grains and interstitial mafic minerals (chlorite and amphibole), locally forming up to $30 \%$ of the rock (Fig. 3b). The plagioclase is completely altered to saussurite. The rock is named leucodiorite because it contains amphibole rather than pyroxene. The relationship of these highly altered rocks to the ca. $610 \mathrm{Ma}$ monzogranite/syenogranite is uncertain, but their close spatial association suggests that they may be of similar age.

\section{Quartz alkali-feldspar syenite to alkali-feldspar syenite}

Quartz alkali-feldspar syenite gradational to alkalifeldspar syenite occurs in the southwestern part of the mountain (Fig. 2). These rocks are typically red, mediumto coarse-grained, and highly magnetic (measured susceptibility values up to $63 \times 10^{-3}$ SI units). They are composed of euhedral to subhedral, coarsely perthitic alkali feldspar and varying amounts of interstitial quartz (Fig. 3c). Dark green euhedral amphibole, altered fayalite(?), and chlorite (after biotite?) locally constitute up to $10 \%$ of the rock. Magnetite is abundant (up to $10 \%$ ), much of it replacing what may have been fayalite crystals, by comparison with similar alteration in syenite in the West Barneys River plutonic suite of the Antigonish Highlands in which elict fayalite has survived (Escarraga 2010). Titanite and apatite are additional accessory phases.

\section{Quartz alkali-feldspar leucosyenite}

Quartz alkali-feldspar leucosyenite occurs in the central part of Porcupine Mountain, west of the metasedimentary unit (Fig. 2). It consists mainly of perthitic alkali feldspar and quartz, and mafic minerals are less abundant than in the quartz alkali-feldspar syenite to alkali-feldspar syenite (Fig. 3d). It also tends to be finer grained, and interstitial granophyric texture is typically present. Magnetite is an abundant accessory mineral, and this unit also is magnetic (measured susceptibility values up to $40 \times 10^{-3} \mathrm{SI}$ units). The leucosyenite intruded the coarse-grained alkali-feldspar syenite, based on what appears to be a chilled margin in the leucosyenite at a sharp contact observed in the southwestern part of the area (Fig. 3e).

\section{Alkali-feldspar granite and syenogranite}

Alkali-feldspar granite gradational to syenogranite forms much of the southeastern part of Porcupine Mountain, and is in faulted contact with the metasedimentary and metavolcanic units, and locally with older granitic rocks (Fig. 2). These rocks are typically more deformed than those in the western belt and in places discrete mylonite zones are present, which appear to correspond to the "gneissoid" beds of Fletcher (1881). In these zones, few of the primary igneous features are preserved, but the rocks appear to have been coarse grained, with abundant quartz and alkali feldspar (Fig. 3f). The mylonite contains abundant quartz ribbons and $\mathrm{K}$-feldspar augen in a fine-grained cataclased quartzfeldspar groundmass. Local areas of quartz alkali-feldspar syenite similar to that in the western area are also present but could not be mapped out as separate units. Overall, these rocks are much less magnetic than the syenitic units in the western part of the complex; the highest measured susceptibility is $9 \times 10^{-3}$ SI units, and most samples have susceptibilities of less than 1. Gabbroic rocks occur in the northwestern part of the unit, intruded by small crosscutting dykes of alkali-feldspar granite. Although the rocks are poorly exposed in that area, the relationships and rock types are similar to those described in the Poor Farm Brook composite pluton in the Antigonish Highlands (White and Archibald 2011; White et al. 2011; Archibald 2012).

\section{Mafic Dykes}

Mafic dykes occur in all units of the Cape Porcupine Complex, as well as in the surrounding Carboniferous rocks (e.g., White and Barr 1998a; Giles et al. 2010). They are typically 1 to $2 \mathrm{~m}$ wide, although the largest observed dyke is about $5 \mathrm{~m}$ wide, and are fine to medium grained with well developed chilled margins. Dykes vary from undeformed with relatively unaltered plagioclase and pyroxene, to intensely altered and dominated by actinolitic amphibole and/or chlorite instead of clinopyroxene. Some dykes cut mylonitic fabrics in the metasedimentary and metavolcanic units. 


\section{U-Pb (Zircon) Geochronology}

A U-Pb (zircon) age of $610 \pm 3 \mathrm{Ma}$ was published previously for syenogranite sample CP98-2 from the monzogranite to syenogranite unit (White et al. 2001). White et al. (2003) reported a U-Pb (zircon) age of $478 \pm$ $3 \mathrm{Ma}$ for sample SMB02-84 from the eastern alkali-feldspar granite unit, but the supporting analytical data were not included. Hence we present those data here.

Sample SMB02-84 is brecciated mylonitic alkali-feldspar granite, in which the original texture was likely coarse but now consists of quartz ribbons around K-feldspar clasts. The sample was processed in the Jack Satterly Laboratory at the Royal Ontario Museum using a jaw crusher for initial crushing, a disk mill for sample reduction to sand-sized particles, and a Wilfley table, heavy liquids (bromoform and methylene iodide) and a Frantz magnetic separator for isolation of heavy mineral fractions. Zircon was selected from the least paramagnetic fraction by hand picking under a binocular microscope. Picked zircons were given an air abrasion treatment to eliminate cracked grains and remove exterior surfaces (Krogh 1982) before final selection of grains for analysis. The weight of each fraction (3 or 4 grains) was measured using a microbalance. As the weights are normally small (generally $<3$ micrograms), both the measured and estimated weights are accurate only to about $\pm 50 \%$. However, this only affects the calculation of $\mathrm{Pb}$ and $\mathrm{U}$ concentrations and has no influence on age data.

The selected grains were washed in $4 \mathrm{~N}$ and then $7 \mathrm{~N} \mathrm{HNO} 3$ and loaded into Teflon bombs with HF and a measured amount of ${ }^{205} \mathrm{~Pb}-{ }^{235} \mathrm{U}$ isotopic tracer solution (Krogh 1973). Dissolution occurred over four to five days at $195{ }^{\circ} \mathrm{C}$. No chemical isolation of $\mathrm{U}$ and $\mathrm{Pb}$ was carried out on the dissolved grains. Fractions were dried down with phosphoric acid and then loaded with silica gel onto outgassed rhenium filaments. The isotopic compositions of $\mathrm{Pb}$ and $\mathrm{U}$ were measured using a single Daly collector with a pulse counting detector in a solid source VG354 mass spectrometer. A detector mass discrimination of $0.14 \%$ per atomic mass unit (AMU) and a deadtime of $22.5 \mathrm{nsec}$ were employed for Daly detector measurements. A thermal source mass discrimination correction of $0.1 \%$ per atomic mass unit for both $\mathrm{Pb}$ and $\mathrm{U}$ was also used. Assigned laboratory blank for $\mathrm{U}$ is $0.2 \mathrm{pg}$. Total measured common $\mathrm{Pb}$ in samples was below $1 \mathrm{pg}$ in nearly all cases and was assigned the isotopic composition of lab blank (see footnotes to Table 1). Error estimates were calculated by propagating known sources of analytical uncertainty for each analysis including ratio variability (within run), uncertainty in the fractionation correction, and uncertainties in the isotopic composition of laboratory blank. Decay constants used are those of Jaffey et al. (1971). All uncertainties are reported at the $95 \%$ confidence level. Discordia lines and concordia intercept ages were calculated by the method of Davis
(1982) using the in-house program ROMAGE, as were average ${ }^{207} \mathrm{~Pb} /{ }^{206} \mathrm{~Pb}$ ages and ${ }^{206} \mathrm{~Pb} /{ }^{238} \mathrm{U}$ ages. Probability of fit measures the scatter of analyses with respect to $\mathrm{a} \mathrm{Pb}$ loss line. A value of around 50\% would be expected for unimodal data sets with correctly chosen analytical errors. Low probability of fit suggests real differences in $\mathrm{Pb}$ loss history and/or zircon crystallization age.

The zircon population consisted of colourless, equant, euhedral prisms of good to excellent quality. Most were four-sided and characterized by either igneous growth zoning or metamorphic overgrowths on igneous cores. The consistency of the age data at $478 \pm 3 \mathrm{Ma}$ (Fig. 4; Table 1) strongly indicates the former. Although igneous units of similar Ordovician age were unknown when this age was first reported (White et al. 2003), an age of $469 \pm 0.5 \mathrm{Ma}$ was obtained recently from quartz syenite of the West Barneys River plutonic suite in the Antigonish Highlands (Escarraga 2010; Escarraga et al. 2012), suggesting a relationship as discussed in more detail below.

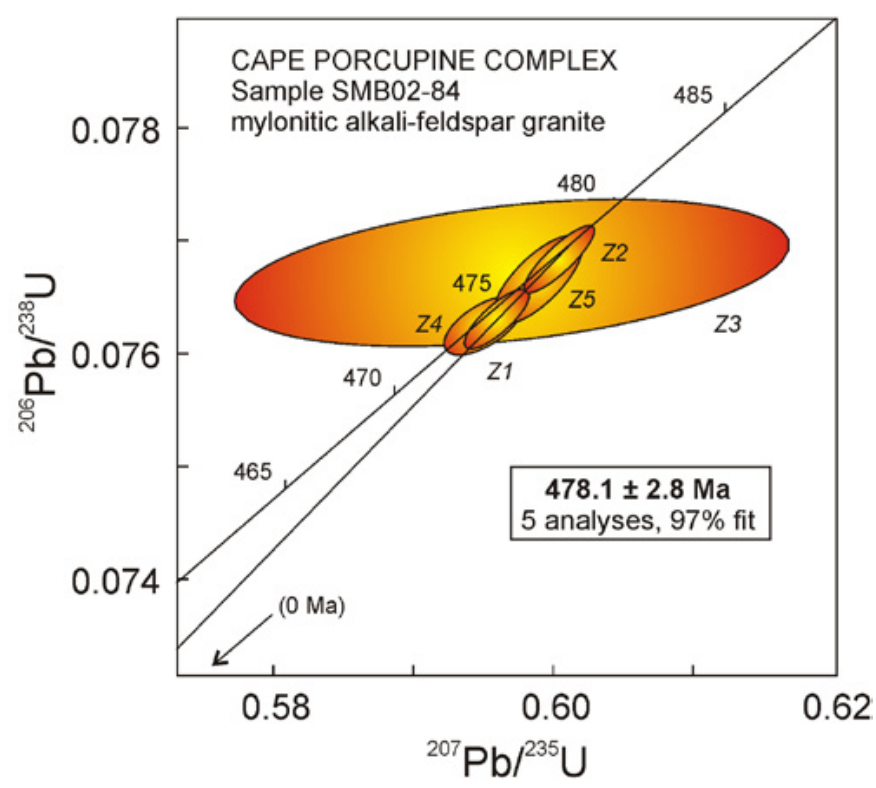

Fig. 4. U-Pb concordia diagram for sample SMB0282 based on data in Table 1.

\section{Geochemistry}

Whole-rock chemical data were obtained for typical samples from igneous and meta-igneous units (Table 2). The data are plotted on diagrams to illustrate their chemical characteristics, and are also compared to data from plutonic units from the Antigonish Highlands based on the work of Escarraga (2010), Murray (2011), and Archibald (2012). The Antigonish Highlands data are shown as fields on the diagrams. 


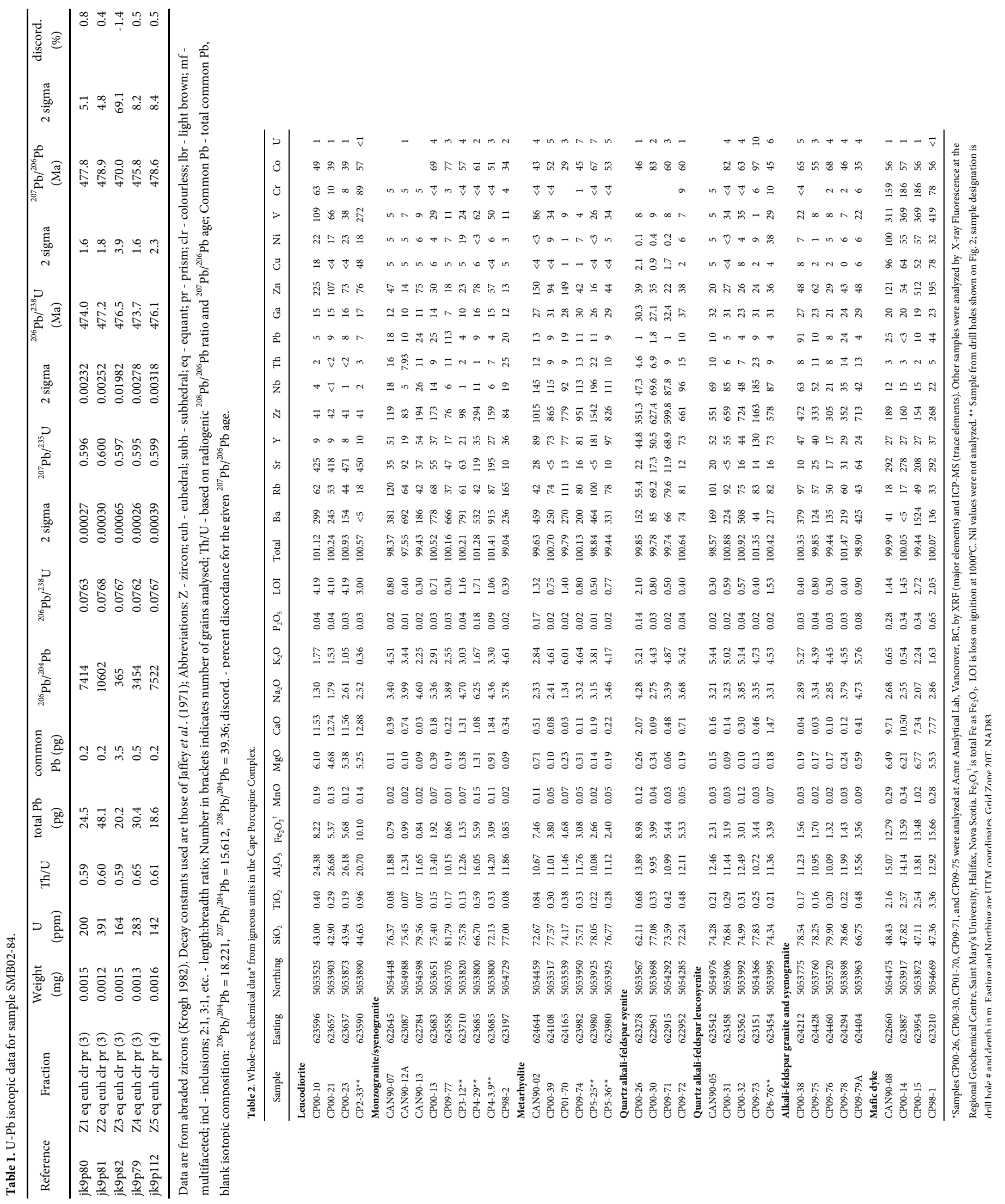


Felsic-intermediate samples

The monzogranite/syenogranite samples (referred to collectively as the granitic suite) range in $\mathrm{SiO}_{2}$ from about 70 to $80 \%$, with one monzogranitic sample containing $67 \%$ (Fig. 5). As a group, they are characterized by negative correlations between $\mathrm{SiO}_{2}$ and $\mathrm{TiO}_{2}, \mathrm{Al}_{2} \mathrm{O}_{3}, \mathrm{Fe}_{2} \mathrm{O}_{3}{ }^{\mathrm{t}}, \mathrm{MgO}$, $\mathrm{CaO}$, and $\mathrm{P}_{2} \mathrm{O}_{5}$, whereas $\mathrm{Na}_{2} \mathrm{O}$ and $\mathrm{K}_{2} \mathrm{O}$ are more scattered.

The quartz alkali-feldspar syenite/alkali-feldspar syenite, quartz alkali feldspar leucosyenite, and alkali-feldspar granite/syenogranite samples (referred to collectively as the syenitic suite) also have $\mathrm{SiO}_{2}$ between $70-80 \%$, except for two alkali-feldspar syenite samples (CP00-26 from the western body and CP09-79A from the eastern body) with $62 \%$ and $66.7 \% \mathrm{SiO}_{2}$, respectively). Both of these samples are dominated by K-feldspar and contain very little modal quartz, consistent with their relatively low $\mathrm{SiO}_{2}$ content compared to other samples. The syenite sample from the western body also contains some separate plagioclase grains and a higher abundance of mafic minerals (including magnetite) than other syenitic samples, consistent with its higher $\mathrm{Al}_{2} \mathrm{O}_{3}, \mathrm{Fe}_{2} \mathrm{O}_{3}{ }^{\mathrm{t}}$, and $\mathrm{CaO}$ (Fig. 5b, c, e). With the exception of these two samples, the other analyzed samples show overall similarity in major element compositions. Compared to the granitic suite, they tend to have lower $\mathrm{Al}_{2} \mathrm{O}_{3}, \mathrm{CaO}$, and $\mathrm{Na}_{2} \mathrm{O}$, and higher $\mathrm{Fe}_{2} \mathrm{O}_{3}{ }^{\mathrm{t}}$ and especially $\mathrm{K}_{2} \mathrm{O}$ (Fig. 5).

The metarhyolite samples also have high $\mathrm{SiO}_{2}$ contents overlapping with those in both the granitic and syenitic suites. Their overall chemical features are more similar to those of the syenitic suite than to the granitic suite, including low $\mathrm{Al}_{2} \mathrm{O}_{3}, \mathrm{CaO}$, and $\mathrm{Na}_{2} \mathrm{O}$ and high $\mathrm{Fe}_{2} \mathrm{O}_{3}{ }^{\mathrm{t}}$ and
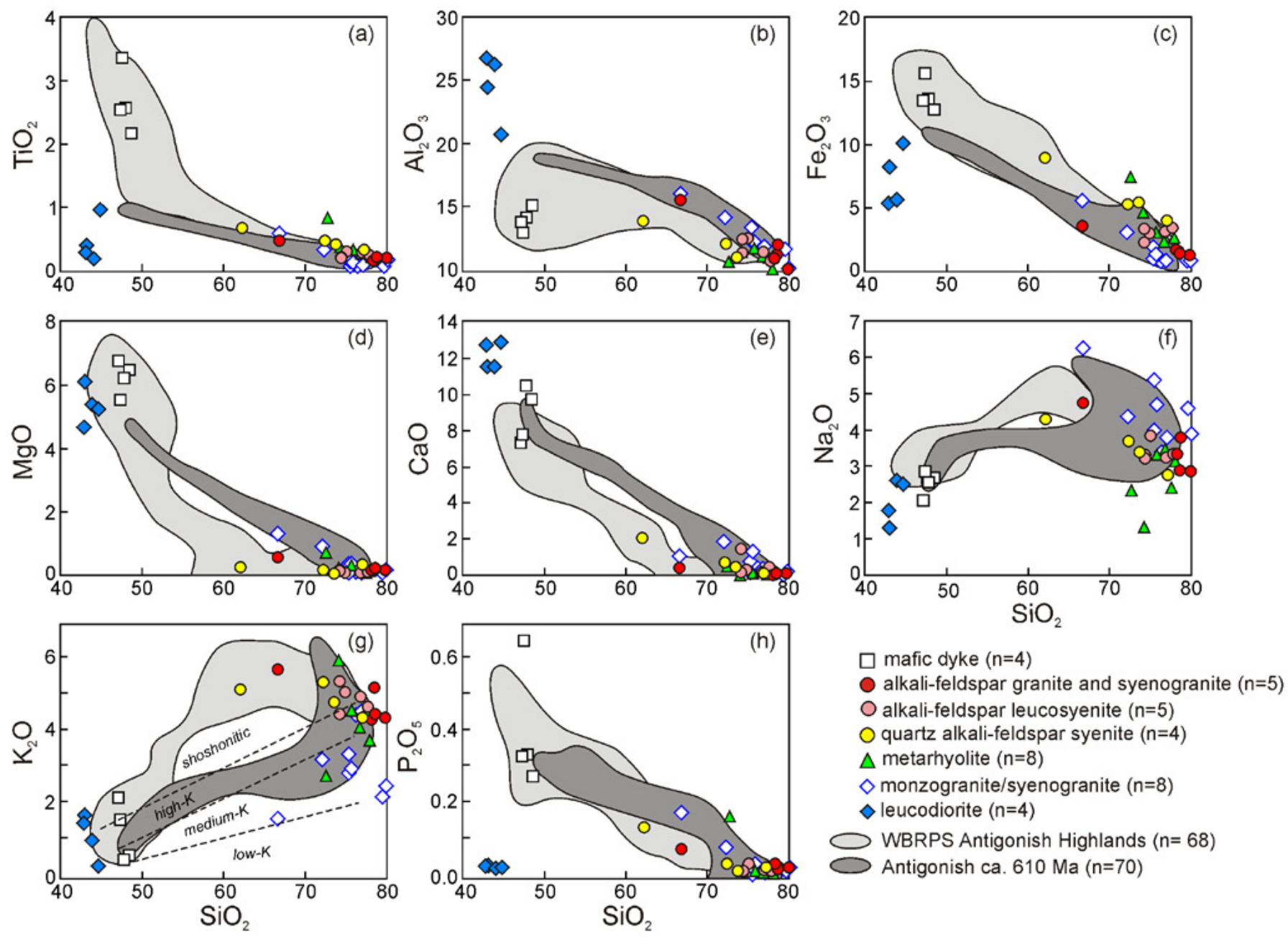

Fig. 5. Major element oxides plotted against $\mathrm{SiO}_{2}$ to illustrate chemical variations in igneous units of the Cape Porcupine Complex. Fields shown for comparison are for ca. 610-605 Ma plutonic rocks and the Ordovician West Barneys River plutonic suite (WBRPS) of the Antigonish Highlands based on data in Escarraga (2010), Murray (2011), and Archibald (2012). 
$\mathrm{K}_{2} \mathrm{O}$, although one sample has low $\mathrm{K}_{2} \mathrm{O}$.

Although designed for volcanic rocks, a plot of $\mathrm{Zr} / \mathrm{TiO}_{2}$ against $\mathrm{Nb} / \mathrm{Y}$ is useful for further illustrating the differences between the syenitic and granitic suites (Fig. 6a). Even with similar $\mathrm{SiO}_{2}$ contents, the syenitic suite has higher $\mathrm{Nb} / \mathrm{Y}$ than the granitic suite, and the samples plot in the alkalic fields as the intrusive equivalents of volcanic rocks such as trachyte and alkali rhyolite. The metarhyolite samples also plot in those fields. In contrast, the granitic samples are subalkalic and plot mainly in the rhyolite +dacite fields. On a plot of $\mathrm{FeO}^{\mathrm{t}} / \mathrm{FeO}^{\mathrm{t}}+\mathrm{MgO}$ ratio against $\mathrm{SiO}_{2}$, the granitic, syenitic, and metarhyolite samples all plot in the ferroan and A-type granite fields, although the granitic samples tend to have lower $\mathrm{FeO}^{\mathrm{t}} / \mathrm{FeO}^{\mathrm{t}}+\mathrm{MgO}$ ratios and some cross into the magnesian granite field of Frost et al. (2001). On diagrams designed to characterize A-type granitoid rocks compared to I- and S-type, the syenitic and metarhyolite samples have high $\mathrm{Ga} / \mathrm{Al}$ ratios and elevated $\mathrm{Zr}$ and $\mathrm{Nb}$ contents typical of A-type granitoid rocks (Fig. 7a, b). In contrast, the granitic samples plot in the field for I- and S-type granitoid rocks. The differences are also apparent on the tectonic setting discrimination diagrams (Fig. 7c, d), on which most of the syenitic and all the metarhyolite samples plot in the withinplate granite fields, whereas the granitic samples lie in the volcanic-arc granite field or slightly into the within-plate granite field, as is typical of evolved I-type granitoid suites.

On all of these diagrams, the granitic samples are similar to the ca. $610-605 \mathrm{Ma}$ plutonic rocks with similar $\mathrm{SiO}_{2}$ contents in the Antigonish Highlands, shown as fields on the diagrams. The Antigonish Highlands plutons are part of an expanded I-type granitoid suite that ranges in composition from dioritic to granitic and likely formed in a continental margin subduction zone (Escarraga 2010; Murray 2011). In contrast, the syenitic samples from the Cape Porcupine Complex, as well as the metarhyolite samples, show similarity to the Ordovician West Barneys River plutonic suite of the Antigonish Highlands. The tectonic setting for the West Barneys River suite is uncertain, but they are A-type granitoid rocks formed in an extensional setting (Escarraga et al. 2012). Hence the chemical data suggest that the igneous units in the Cape Porcupine Complex are correlative with units of similar ages in the Antigonish Highlands.

Rare-earth element data are not available for all of the samples from the Cape Porcupine Complex, but existing data are consistent with this proposed correlation (Fig. 8). Two granitic samples show moderate light REE enrichment and flat-heavy REE patterns, similar to the field defined by samples from ca. 610-605 Ma plutons in the Antigonish Highlands (Fig. 8a; Table 3). Four syenitic samples and one metarhyolite sample show similar chondrite-normalized patterns, with light REE enrichment (200 to 400 times chondritic values) and gently sloping heavy REE at 20 to 40 times chondritic values, and lie in the field defined by
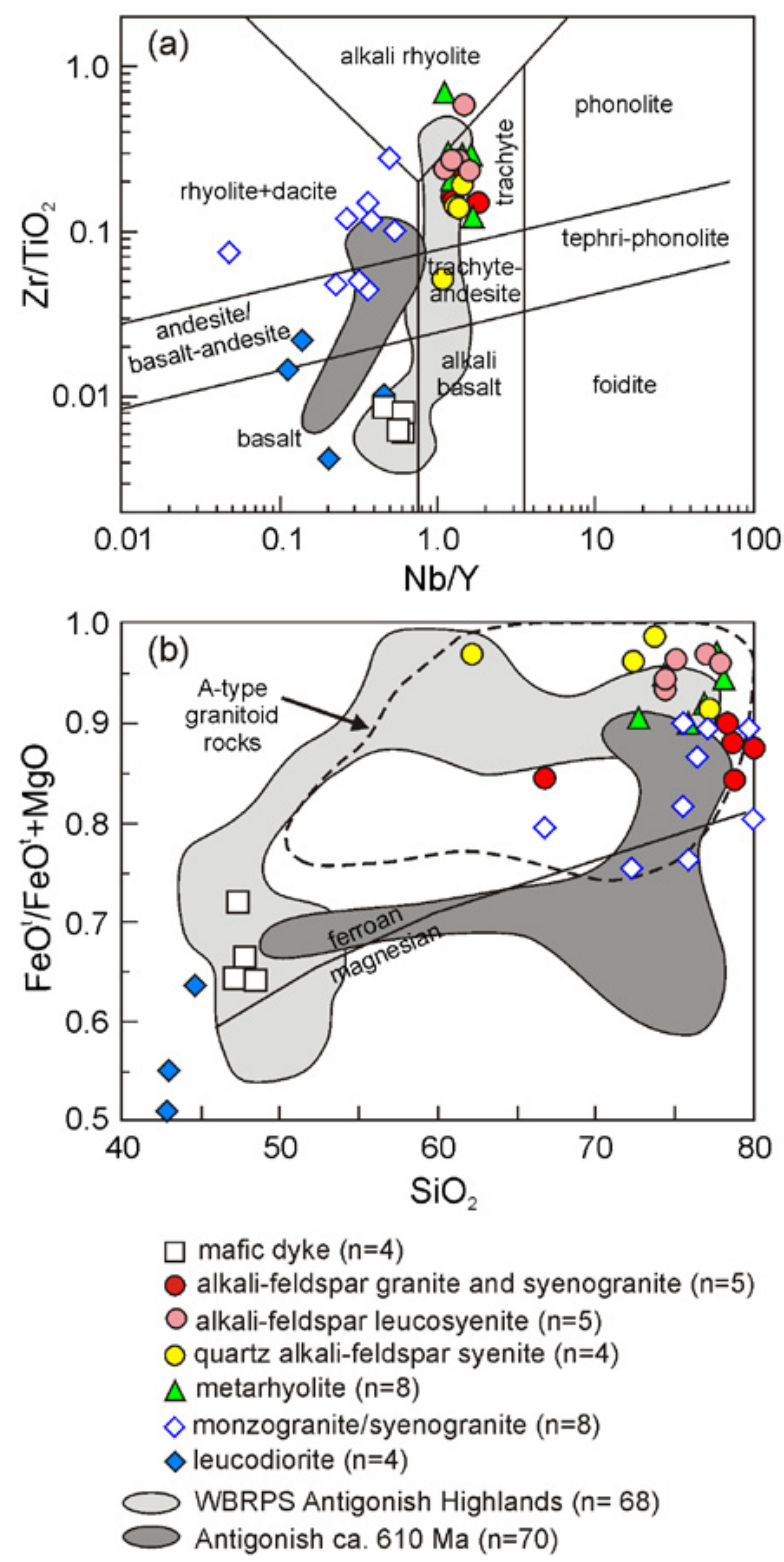

Fig. 6. Plots illustrating chemical characteristics of igneous samples from the Cape Porcupine Complex. (a) $\mathrm{Zr}_{2} / \mathrm{TiO}_{2}$ against $\mathrm{Nb} / \mathrm{Y}$ with fields after Winchester and Floyd (1977), as revised by Pearce (1996). (b) $\mathrm{FeO}^{t} /\left(\mathrm{FeO}^{t}+\mathrm{MgO}\right)$ against $\mathrm{SiO}_{2}$ with A-type granite field and ferroan-magnesian dividing line from Frost et al. (2001). Fields shown for comparison are for ca. 610-605 Ma plutonic rocks and the Ordovician West Barneys River plutonic suite of the Antigonish Highlands based on data in Escarraga (2010), Murray (2011), and Archibald (2012). 

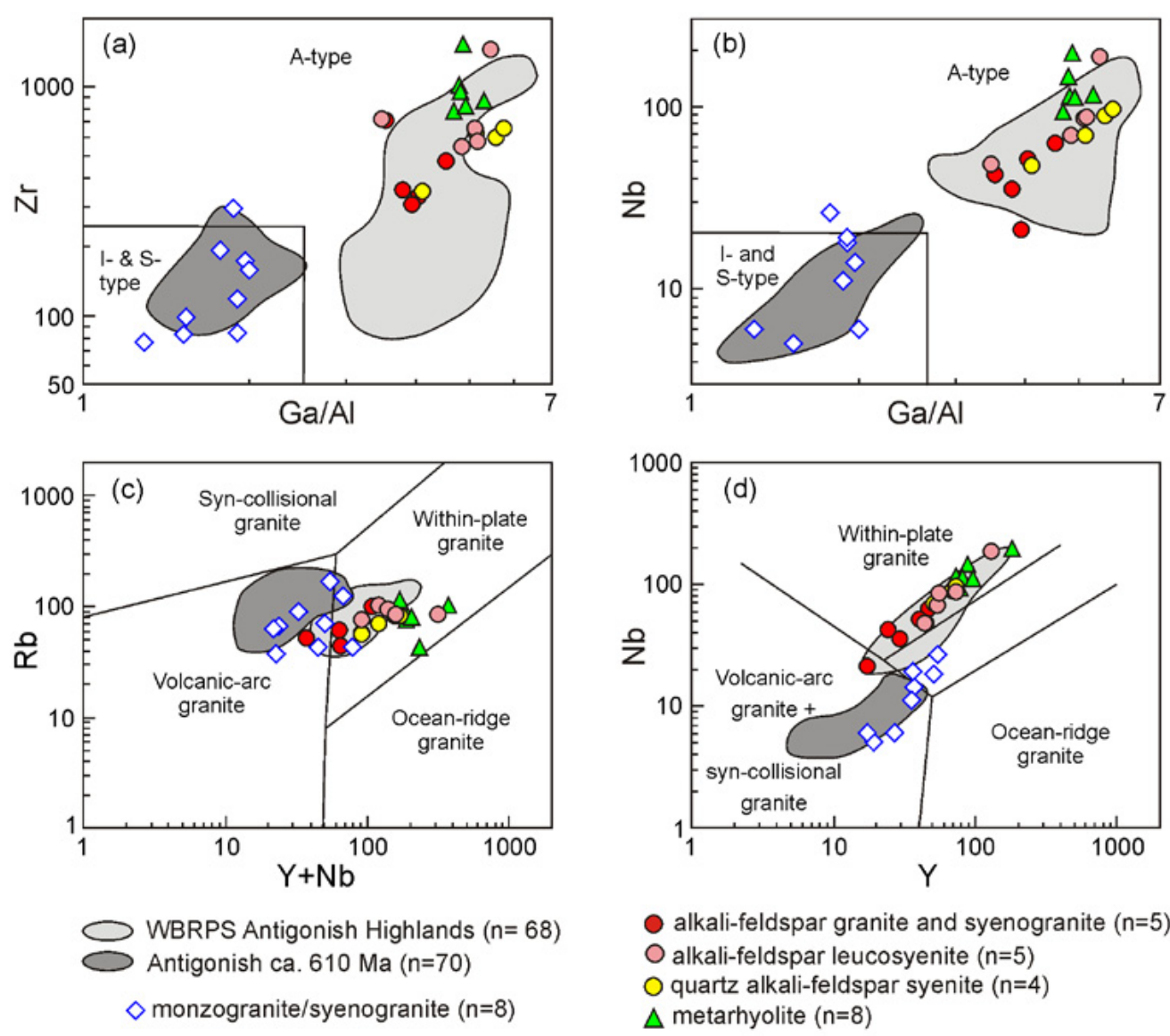

O alkali-feldspar granite and syenogranite $(n=5)$

Oalkali-feldspar leucosyenite $(n=5)$

O quartz alkali-feldspar syenite $(n=4)$

$\triangle$ metarhyolite $(n=8)$

Fig. 7. Granitoid discrimination diagrams showing felsic samples from the Cape Porcupine Complex. (a) $\mathrm{Zr}$ against Ga/ Al. (b) $\mathrm{Nb}$ aginst $\mathrm{Ga} / \mathrm{Al}$. (c) Rb against $\mathrm{Y}+\mathrm{Nb}$. (d) $\mathrm{Y}$ against $\mathrm{Nb}$. Fields in (a) and (b) are after Whalen et al. (1987); fields in (c) and (d) are after Pearce et al. (1984). Fields shown for comparison are for intermediate-felsic samples from ca. 610-605 Ma plutonic rocks and the Ordovician West Barneys River plutonic suite of the Antigonish Highlands based on data in Escarraga (2010), Murray (2011), and Archibald (2012).
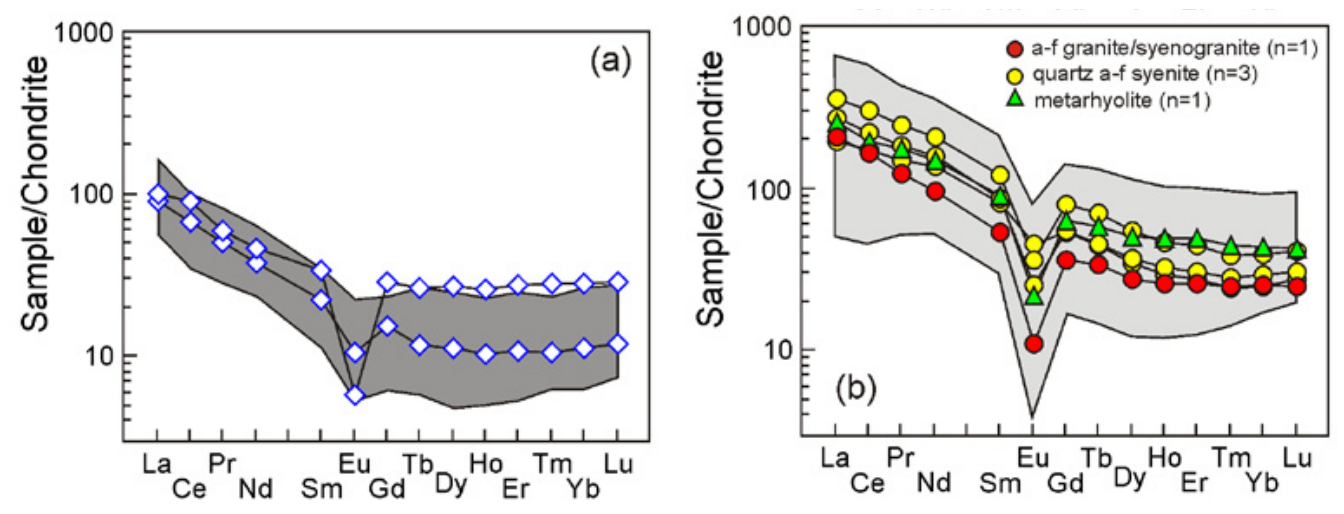

Fig. 8. Chondrite-normalized rare-earth element diagrams. (a) Granitic samples from the Cape Porcupine Complex with grey field enclosing felsic samples from ca. 610-605 Ma plutons in the Antigonish Highlands using data in Escarraga (2010) and Murray (2011). (b) Syenitic and metarhyolite samples from the Cape Porcupine Complex; grey field represents felsic samples from the West Barneys River plutonic suite. Chondrite-normalizing values are from Sun and McDonough (1989). 
Table 3. Rare-earth element and Hf, Cs, Sc, Ta, Mo, and Au data ${ }^{\star}$ from igneous units in the Cape Porcupine Complex.

\begin{tabular}{|c|c|c|c|c|c|c|c|c|c|c|c|c|c|c|c|c|c|c|c|c|}
\hline Sample & Hf & Cs & $\mathrm{Sc}$ & $\mathrm{Ta}$ & Mo & $\mathrm{Au}$ & $\mathrm{La}$ & $\mathrm{Ce}$ & $\operatorname{Pr}$ & $\mathrm{Nd}$ & Sm & $\mathrm{Eu}$ & Gd & $\mathrm{Tb}$ & Dy & Ho & $\mathrm{Er}$ & $\operatorname{Tm}$ & $\mathrm{Yb}$ & $\mathrm{Lu}$ \\
\hline \multicolumn{21}{|c|}{ Monzogranite/syenogranite } \\
\hline CAN90-12A & 5.5 & 0.3 & & 2.4 & 0.3 & & 21.14 & 40.82 & 4.77 & 17.60 & 3.41 & 0.60 & 3.14 & 0.44 & 2.85 & 0.58 & 1.77 & 0.27 & 1.89 & 0.30 \\
\hline CP98-2 & 6.9 & 0.4 & & 3.0 & & & 23.32 & 54.42 & 5.62 & 21.54 & 5.15 & 0.33 & 5.84 & 0.99 & 6.78 & 1.46 & 4.53 & 0.71 & 4.70 & 0.73 \\
\hline \multicolumn{21}{|l|}{ Metarhyolite } \\
\hline СР01-70 & 19.8 & 0.4 & 1.0 & 6.0 & 3.5 & 0.5 & 60.20 & 117.10 & 16.57 & 68.50 & 13.78 & 1.27 & 12.88 & 2.18 & 12.75 & 2.74 & 8.04 & 1.12 & 7.36 & 1.08 \\
\hline \multicolumn{21}{|c|}{ Quartz alkali-feldspar syenite } \\
\hline СР00-26 & 8.9 & 0.2 & 4.0 & 3.4 & 0.5 & 0.5 & 45.80 & 104.10 & 13.97 & 62.90 & 12.30 & 2.60 & 10.92 & 1.64 & 8.78 & 1.64 & 4.54 & 0.62 & 4.22 & 0.69 \\
\hline СР00-30 & 15.1 & 0.3 & 1.0 & 4.7 & 0.2 & 0.5 & 63.60 & 133.30 & 17.20 & 72.80 & 13.08 & 1.47 & 11.13 & 1.70 & 9.20 & 1.82 & 5.06 & 0.71 & 4.92 & 0.77 \\
\hline СР09-71 & 15.0 & 0.3 & 1.0 & 5.8 & 0.4 & 0.5 & 83.00 & 183.30 & 23.22 & 95.00 & 18.32 & 2.07 & 16.11 & 2.60 & 13.72 & 2.61 & 7.27 & 0.97 & 6.59 & 1.02 \\
\hline \multicolumn{21}{|c|}{ Alkali-feldspar granite and syenogranite } \\
\hline CP09-75 & 10.3 & 0.1 & 1.0 & 3.4 & 3.3 & 0.5 & 48.90 & 100.80 & 11.60 & 44.70 & 8.14 & 0.63 & 7.29 & 1.25 & 6.97 & 1.45 & 4.28 & 0.63 & 4.27 & 0.62 \\
\hline
\end{tabular}

*Samples CAN90-12A and CP98-2 were analyzed by ICP-MS using the $\mathrm{Na}_{2} \mathrm{O}_{2}$ sinter method at Memorial University, St. John's, NL. Remaining samples were analyzed at Acme Analytical Lab, Vancouver, BC, also by ICP-MS. Blanks indicate no analysis. Sample locations are listed in Table 2 and shown on Figure 2.

felsic samples from the West Barneys River suite (Fig. 8b). The strong negative $\mathrm{Eu}$ anomalies in all of these samples are consistent with feldspar fractionation, documented to be a major factor in magma evolution in both the ca. 610-605 $\mathrm{Ma}$ and Ordovician suites in the Antigonish Highlands (Escarraga 2010; Archibald 2012; Escarraga et al. 2012).

\section{Mafic rocks}

The four analyzed leucodiorite samples are low in $\mathrm{SiO}_{2}$ (40-45\%), suggesting that they may originally have been leucogabbro. Their high $\mathrm{Al}_{2} \mathrm{O}_{3}$ and $\mathrm{CaO}$ are consistent with the abundance of plagioclase, although its original composition cannot be determined due to pervasive

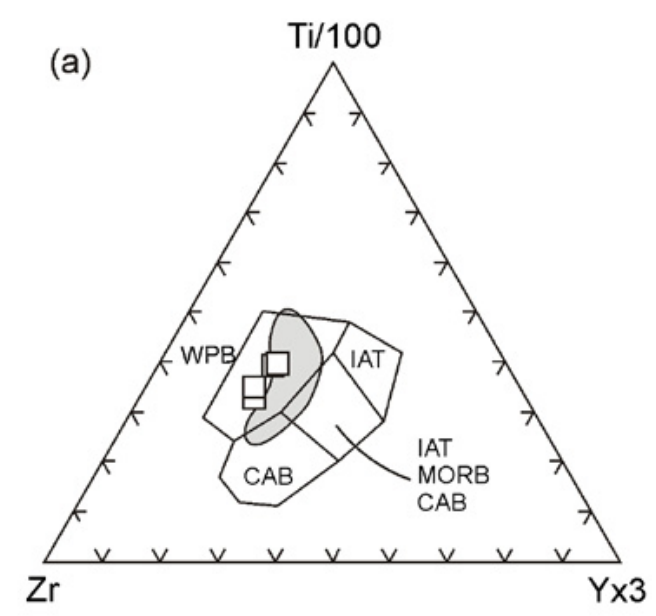

alteration to epidote, zoisite/clinozoisite, and high $\mathrm{MgO}$ and $\mathrm{Fe}_{2} \mathrm{O}_{3}{ }^{\mathrm{t}}$ with the abundance of chlorite and amphibole. These highly altered rocks are notably low in $\mathrm{TiO}_{2}$ and $\mathrm{P}_{2} \mathrm{O}_{5}$. Their distinctly different compositions suggest that they are not directly related to the other igneous units in the Cape Porcupine Complex.

Four mafic dykes, one cutting each of the metasedimentary and metarhyolite units and two in the ca. $610 \mathrm{Ma}$ monzogranite/syenogranite unit, were also analyzed. All four dykes contain about $48 \% \mathrm{SiO}_{2}$ and show chemical similarities to one another and to gabbroic samples with similar $\mathrm{SiO}_{2}$ contents in the West Barneys River plutonic suite (Fig. 5). Especially notable are the high $\mathrm{TiO}_{2}$ and $\mathrm{Fe}_{2} \mathrm{O}_{3}^{\mathrm{t}}$ (Fig. 5a, c). Like the West Barneys River gabbroic samples, the dykes are tholeiitic transitional to alkalic based

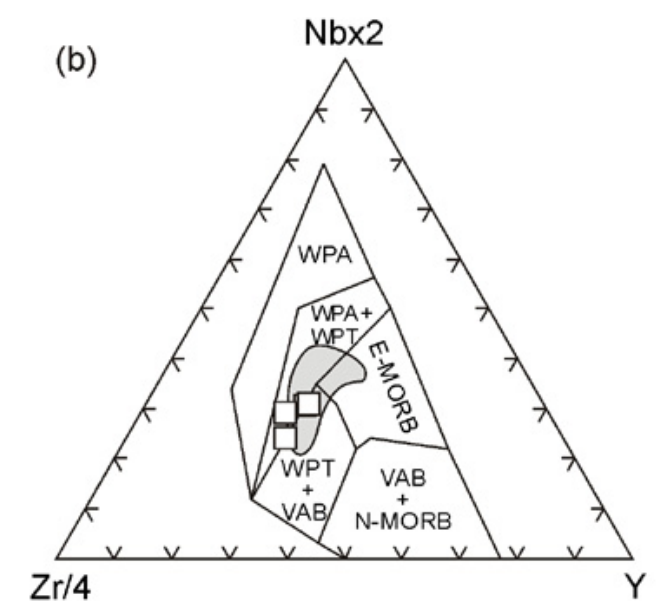

Fig. 9. Mafic dyke samples from the Cape Porcupine Complex $(n=4)$ plotted on tectonic setting discrimination diagrams. Grey field encloses gabbroic samples from the West Barneys River plutonic suite in the Antigonish Highlands based on data from Archibald (2012). Fields in (a) are from Pearce and Cann (1973) and in (b) from Meschede (1986). 
on $\mathrm{Nb} / \mathrm{Y}$ ratio (Fig. 6a). On tectonic setting discrimination diagrams for mafic rocks, they plot in the within-plate basalt fields, and also in the field defined by mafic samples from the West Barneys River suite (Fig. 9a, b). These chemical similarities to gabbroic rocks in the West Barneys River plutonic suite suggest that the analyzed mafic dykes may also be Ordovician. If so, they indicate a minimum age for the metasedimentary and metarhyolite units, and for the mylonitic deformation as the mafic dykes in those units are not mylonitic.

\section{DISCUSSION}

Based on the presence of metasedimentary, metavolcanic and granitic rocks, Fletcher (1881, 1984), Ferguson (1946), Ferguson and Weeks (1950), and Keppie (2000) correlated the rocks at Cape Porcupine with the metamorphic and granitic rocks exposed in the area now known as the Bras d'Or terrane of adjacent Cape Breton Island (Fig. 1). However, the metamorphic rocks in the Bras d'Or terrane area characterized by abundant marble and calc-silicate rocks that are not present in the Cape Porcupine Complex (e.g., Raeside and Barr 1990; Keppie et al. 1998). Also, granitoid rocks in the Bras d'Or terrane are not mineralogically or texturally similar to those in the Cape Porcupine Complex. Their ages of ca. 560-550 Ma (e.g., Keppie et al. 2000; White et al. 2003) are not similar to the ca. $610 \mathrm{Ma}$ and $478 \mathrm{Ma}$ ages obtained from the Cape Porcupine Complex granitic and syenitic units, respectively.

White et al. (2003) assumed that all of the granitoid rocks in the western part of the Cape Porcupine Complex are ca. $610 \mathrm{Ma}$ and that those in the eastern belt are ca. 478 $\mathrm{Ma}$, and hence that the eastern and western granitoid belts are not related. However, the chemical data presented here suggest that ca. $610 \mathrm{Ma}$ granitoid rocks are not as abundant as assumed by White et al. (2003) and that in fact most of the plutonic rocks in the western part of the complex are syenitic, like those in the eastern part. White et al. (2003) suggested that the close spatial association between the metarhyolite unit and the eastern syenitic unit indicated that they might be of similar age. The chemical data presented here support this interpretation and suggest that the metarhyolite could be the extrusive equivalent of the ca. 478 Ma syenitic suite.

White et al. $(2001,2003)$ recognized that the presence of ca. 610 Ma granitic rocks in the Cape Porcupine Complex suggests a connection with Avalonia, where volcanic and plutonic rocks of approximately that age are a characteristic feature (e.g., Hibbard et al. 2006; Thompson et al. 2010). However, White et al. (2003) were puzzled by the ca. $478 \mathrm{Ma}$ age because in 2003, no Ordovician ages had been reported from Avalonia in the Antigonish Highlands or Mira terrane. At that time, the volcanic rocks of the Dunn Point Formation in the western Antigonish Highlands (Fig. 1) were thought to be Silurian, and hence a connection with that igneous activity was not considered. However, subsequent dating showed that the Dunn Point Formation is Ordovician (ca. $460 \mathrm{Ma}$; Hamilton and Murphy 2004) and more recent work has demonstrated that overlying rhyolite of the McGillivray Brook Formation (Fig. 1) has a similar Ordovician age of $454.5 \pm 0.7 \mathrm{Ma}$ (Murphy et al. 2012). These felsic rocks have compositions similar to A-type granites and were interpreted to represent on-going extension following on from that represented by the West Barneys River plutonic suite at ca. $469 \mathrm{Ma}$ (Escarraga et al. 2012; Murphy et al. 2012). The syenitic suite and metarhyolite in the Cape Porcupine Complex appear to extend this period of A-type extensional and bimodal magmatism in this part of Avalonia back to at least $478 \mathrm{Ma}$.

The age of the metasedimentary unit in the Cape Porcupine Complex remains unresolved. However, the pelitic (muscovite-rich) composition of the metasedimentary unit is more similar to the sedimentary rocks interbedded with flows of the mid-Ordovician Dunn Point and McGillivray Brook formations than to the Neoproterozoic sedimentary units of the Antigonish Highlands (White et al. 2011). This interpretation is consistent with the close association and possible interlayering of the metarhyolite and metasedimentary units of the Cape Porcupine Complex, but if correct, indicates that the metarhyolite may be at least 18 million years younger than the ca. 478 Ma syenitic suite.

The absence of any of these units, distinctive in both age and petrological characteristics, on the eastern side of the Strait of Canso supports the importance of major offset along the Canso Fault, as postulated by Barr and Raeside (1989). The mylonitic fabric so pervasive in rocks in the eastern half of the Cape Porcupine Complex (Fig. 2) may be direct evidence for the Canso Fault which offsets terranes of Cape Breton Island relative to those of northern mainland Nova Scotia (Fig. 1, inset).

\section{CONCLUSIONS}

White et al. (2003) concluded that the relationship of the Cape Porcupine Complex to other igneous and metamorphic rocks in adjacent parts of Cape Breton Island and northern mainland Nova Scotia was unclear, and hence that its terrane affiliation was uncertain. Based on age and petrological similarities, it is likely that the ca. 610 Ma granitic rocks in the Cape Porcupine Complex formed as part of the same plutonic event as rocks of similar age in the Antigonish Highlands. The Ordovician age and A-type characteristics of the syenitic rocks in the Cape Porcupine Complex match well with those of the syenitic rocks in the West Barneys River plutonic suite in the Antigonish Highlands, and the age of $478 \pm 3$ Ma obtained for alkali-feldspar granite in the 
Cape Porcupine Complex extends this episode of igneous activity back to at least the Early Ordovician. Hence the results of this study show that the Cape Porcupine Complex is geologically linked to the Antigonish Highlands and is no longer a geological orphan in terrane reconstructions. The lack of similarities between the components of the Cape Porcupine Complex and rocks in adjacent Cape Breton Island further demonstrates the regional significance of the Canso Fault in tectonic reconstructions.

\section{NOTE ADDED IN PROOF}

A preliminary $\mathrm{U}-\mathrm{Pb}$ (zircon) age of $482 \pm 4 \mathrm{Ma}$ from quartz alkali feldspar leucosyenite sample CAN90-5 (Fig. 2) confirms that the leucosyenite unit is Ordovician in age and supports the correlations proposed here based on petrological data.

\section{ACKNOWLEDGEMENTS}

This work was funded in part by a Discovery Grant to Sandra Barr from the Natural Sciences and Engineering Research Council of Canada. We are grateful to journal reviewers Andy Kerr and Brendan Murphy for their helpful reviews which resulted in substantial improvements in the manuscript.

\section{REFERENCES}

Archibald, D.B 2012. Field relations, petrology, and tectonic setting of the Ordovician West Barneys River plutonic suite, southern Antigonish Highlands, Nova Scotia. Unpublished M.Sc thesis, Acadia University, Wolfville, Nova Scotia, $259 \mathrm{p}$.

Barr, S. M., and Raeside, R. P. 1989. Tectonostratigraphic terranes in Cape Breton Island, Nova Scotia: implications for the configuration of the northern Appalachian orogen. Geology, 17,pp. 822-825. http://dx.doi.org/10.1130/00917613(1989)017<0822:TSTICB >2.3.CO;2

Barr, S. M., White, C. E., and Macdonald, A. S. 1996. Stratigraphy, tectonic setting, and geological history of Late Precambrian volcanic-sedimentary-plutonic belts in southeastern Cape Breton Island, Nova Scotia. Geological Survey of Canada, Bulletin 468. $84 \mathrm{p}$.

Davis, D.W. 1982. Optimum linear regression and error estimation applied to U-Pb data: Canadian Journal of Earth Sciences, 19, pp. 2141-2149. http://dx.doi. org/10.1139/e82-188

Escarraga, E.A. 2010. Field relationships, petrology, age, and tectonic setting of previously inferred Devonian-
Carboniferous granitic plutons in the Antigonish Highlands, Nova Scotia. Unpublished M.Sc thesis, Acadia University, Wolfville, Nova Scotia, 183 p.

Escarraga, E.A., Barr, S.M., Murphy, J.B., and Hamilton, M.A. 2012. Ordovician A-type plutons in the Antigonish Highlands, Nova Scotia. Canadian Journal of Earth Sciences, 49, pp. 329-345.

Ferguson, S. A. 1946. Strait of Canso, Antigonish, Guysborough, Inverness and Richmond counties, Nova Scotia; Department of Mines and Resources, Mines and Geology Branch, Geological Survey, Paper 46-12; Map 46-12a, scale 2 inches to 1 mile.

Ferguson, S. A., and Weeks, L. J. 1950. Mulgrave, Nova Scotia. Geological Survey of Canada, Map 995A, scale 1:63 360 .

Fletcher, H. 1881. Report on parts of the counties of Richmond, Inverness, Guysborough and Antigonish, Nova Scotia, 1881. Geological Survey of Canada, Reports of Exploration and Survey, 1879-80, Part F.

Fletcher, H. 1884. Map No. 22, Province of Nova Scotia (Island of Cape Breton); Geological Survey of Canada, scale 1:63 360 .

Frost, B.R., Barnes, C.G., Collins, W.J., Arculus, R.J., Ellis, D.J., and Frost, C.D. 2001. A geochemical classification for granitic rocks. Journal of Petrology, 42, pp. 2033-2048. http://dx.doi.org/10.1093/petrology/42.11.2033

Giles, P.S., Naylor, R.D., Teniere, P.J., White, C.E., Barr, S.M., DeMont, G.J., and Force, E.R. 2010. Bedrock geology map of the Port Hawkesbury area, Part of NTS Sheets 11F/06, $11 \mathrm{~F} / 07,11 \mathrm{~F} / 10,11 \mathrm{~F} / 11$ and $11 \mathrm{~F} / 15$, Inverness, Richmond, Guysborough, and Antigonish Counties, Nova Scotia. Nova Scotia Department of Natural Resources, Mineral Resources Branch, Open File Map Me 2010-006, scale 1:50 000 .

Graves, M. 1990. Geology and lithological correlation of Cape Porcupine, Aulds Cove, Guysborough County, Nova Scotia. Atlantic Geology, 26, p. 171.

Hamilton, M.A., and Murphy, J.B. 2004. Tectonic significance of a Llanvirn age for the Dunn Point volcanic rocks, Avalon terrane, Nova Scotia: implications for the evolution of Iapetus and Rheic oceans. Tectonophysics, 379, pp. 199209. http://dx.doi.org/10.1016/j.tecto.2003.11.006

Hibbard, J.P., van Staal, C.R., Rankin, D.W., and Williams, H. 2006. Lithotectonic map of the Appalachian orogen, Canada - United States of America: Geological Survey of Canada Map 02096A, 2 sheets, scale 1:1 500000.

Hutchison, C.S. 1974. Laboratory handbook of petrographic techniques. Wiley Interscience, New York, 527 p.

Jaffey, A.H., Flynn, K.F., Glendenin, L.E., Bentley, W.C., and Essling, A.M. 1971. Precision measurement of half-lives and specific activities of 235U and 238U. Physical Review, 4, pp. 1889-1906.

Keppie, J. D. (compiler) 2000. Geological Map of the Province of Nova Scotia. Nova Scotia Department of 
Natural Resources, Map ME 2000-1, scale 1:500 000.

Keppie, J.D., Davis, D.W., and Krogh, T.E. 1998. U-Pb geochronological constraints on Precambrian stratified units in the Avalon Composite Terrane of Nova Scotia, Canada: tectonic implications. Canadian Journal of Earth Sciences, 35, pp. 222-236. http://dx.doi.org/10.1139/e97109

Keppie, J. D., Dostal, J., Dallmeyer, R. D., and Doig, R. 2000. Superposed Neoproterozoic and Silurian magmatic arcs in central Cape Breton Island, Canada: geochemical and geochronological constraints; Geological Magazine, 137, pp. 137-153. http://dx.doi.org/10.1017/ S0016756800003769

King, M.S. 2002. A geophysical interpretation of the MiraBras d'Or terrane boundary, southeastern Cape Breton Island, Nova Scotia. Unpublished M.Sc thesis, Acadia University, Wolfville, Nova Scotia, 195 p.

Krogh, T.E., 1973. A low contamination method for hydrothermal decomposition of zircon and extraction of $\mathrm{U}$ and $\mathrm{Pb}$ for isotopic age determinations. Geochimica et Cosmochimica Acta, 37, pp. 485-494. http://dx.doi. org/10.1016/0016-7037(73)90213-5

Krogh, T. E. 1982. Improved accuracy of U-Pb zircon ages by creation of more concordant systems using an air abrasion technique. Geochimica et Cosmochimica Acta, 37, pp. 637-649. http://dx.doi.org/10.1016/00167037(82)90165-X

Meschede, M. 1986. A method of discriminating between different types of mid-ocean ridge basalts and continental tholeiites with the Nb-Zr-Y diagram. Chemical Geology, 56, pp. 207-218. http://dx.doi.org/10.1016/00092541(86)90004-5

Murphy, J.B., Keppie, J.D., and Hynes, A.J. 1991. The geology of the Antigonish Highlands, Nova Scotia; Geological Survey of Canada, Paper 89-10, 115 p. http://dx.doi. org/10.4095/132458

Murphy,J.B., Dostal, J., and Keppie,J.D.2008. NeoproterozoicEarly Devonian Magmatism in the Antigonish Highlands, Avalon terrane, Nova Scotia: tracking the evolution of the mantle and crustal sources during the evolution of the Rheic Ocean. Tectonophysics, 461, pp. 181-201. http:// dx.doi.org/10.1016/j.tecto.2008.02.003

Murphy, J.B., Hamilton, M.A., and LeBlanc, B. 2012. Tectonic significance of the late Ordovician silicic magmatism, Avalon terrane, northern Antigonish Highlands, Nova Scotia. Canadian Journal of Earth Sciences, 49, pp. 346358. http://dx.doi.org/10.1139/e11-012

Murray, D.M. 2011. Field, petrographic, and chemical characterization of the Neoproterozoic Ohio Pluton of the Antigonish Highlands, Nova Scotia. Unpublished B.Sc. thesis, St. Francis Xavier University, Antigonish, Nova Scotia, $25 \mathrm{p}$.

Pearce, J.A. 1996. A users guide to basalt discrimination diagrams, in Wynam, D.A., ed., Geological Association of
Canada, Short Course Notes, 12, pp. 79-113.

Pearce, J.A., and Cann, J.R. 1973. Tectonic setting of basic volcanic rocks determined using trace element analyses. Earth and Planetary Science Letters, 19, pp. 290-300. http://dx.doi.org/10.1016/0012-821X(73)90129-5

Pearce, J. A., Harris, N. B. W., and Tindle, A. G. 1984. Trace element discrimination diagrams for the tectonic interpretation of granitic rocks. Journal of Petrology, 25, pp. 956-983.

Raeside, R. P., and Barr, S. M. 1990. Geology and tectonic development of the Bras d'Or suspect terrane, Cape Breton Island, Nova Scotia. Canadian Journal of Earth Sciences, 27, pp. 1317-1381. http://dx.doi.org/10.1139/ e90-147

Reynolds, P.H., Barr, S.M., White, C.E., and Ténière, P.J. 2004. 40Ar/39Ar dating in the Lochaber - Mulgrave area, northern mainland Nova Scotia: Implications for timing of regional metamorphism and sediment provenance in the Late Devonian - Early Carboniferous Horton Group. Canadian Journal of Earth Sciences, 41, pp. 987-996. http://dx.doi.org/10.1139/e04-050

Streckeisen, A. 1976. To each plutonic rock its proper name. Earth Science Reviews, 12, pp. 1-33. http://dx.doi. org/10.1016/0012-8252(76)90052-0

Sun, S.S., and McDonough, W.F. 1989. Chemical and isotopic systematics of oceanic basalts: implications for mantle composition and processes. Geological Society, London, Special Publications, 42, pp. 313-345. http:// dx.doi.org/10.1144/GSL.SP.1989.042.01.19

Thompson, M.D., Ramezani, J., Barr, S.M., and Hermes, O.D. 2010. Tectonic implications of some revised $\mathrm{U}-\mathrm{Pb}$ (zircon) ages of Ediacaran granitoid rocks in the southeastern New England Avalon zone. In From Rodinia to Pangea: The Lithotectonic Record of the Appalachian Region. Edited by R.P. Tollo, M.J. Bartholomew, J.P. Hibbard, and P.M. Karabinos. P.M. Geological Society of America Memoir 206, pp. 231-250. http://dx.doi. org/10.1130/2010.1206(11)

Whalen, J.B., Currie, K.L., and Chappell, B.W. 1987. A-type granites: geochemical characteristics, discrimination, and petrogenesis. Contributions to Mineralogy and Petrology, 95, pp. 407-419. http://dx.doi.org/10.1007/BF00402202

White, C.E., and Archibald, D.B. 2011. Preliminary geology of the southern Antigonish Highlands, northern mainland Nova Scotia. Nova Scotia Department of Natural Resources Mineral Resources Branch Open File Illustration ME 2011-1.

White, C. E., and Barr, S. M. 1998a. Geology of the Guysborough-Mulgrave-L'Ardoise area: a progress report; in Minerals and Energy Branch, Report of Activities 1998, eds. D. R. MacDonald and K. A. Mills; Nova Scotia Department of Natural Resources, Report ME 1999-1, pp. 105-117.

White, C. E., and Barr, S. M. 1998b. Preliminary geological 
map of Guysborough, Richmond and Antigonish counties (parts of NTS sheets 11E/08, 11F/05, 11F/06, 11F/10, $11 \mathrm{~F} / 11,11 \mathrm{~F} / 12$ and 11F/15), Nova Scotia, Canada; Nova Scotia Department of Natural Resources, Minerals and Energy Branch, Open File Map 1998-1, scale 1:100 000.

White, C.E., Barr, S.M., Ketchum, J.W.F., and Ethier, M. 2001. Geology of the Cape Porcupine Complex (NTS11F/11), Guysborough County, Nova Scotia. In Nova Scotia Department of Natural Resources, Minerals and Energy Branch, Report of Activities 2000. Edited by D.R. MacDonald. Report ME 2001-1, p. 83-93.

White, C.E., Barr, S.M., and Ketchum, J.W.F. 2003. New age controls on rock units in pre-Carboniferous basement blocks in southwestern Cape Breton Island and adjacent mainland Nova Scotia. In Nova Scotia Department of Natural Resources, Minerals and Energy Branch, Report of Activities 2002. Edited by D.R. MacDonald. Report ME 2003-1, 163-178.

White, C.E., Archibald, D.B., MacHattie, T.G., and Escarraga, E.A. 2011. Preliminary geology of the southern Antigonish Highlands, northern mainland Nova Scotia. In Mineral Resources Branch, Report of Activities 2010. Edited by D.R. MacDonald. Nova Scotia Department of Natural Resources, Report ME 2011-1, pp. 145-164.

Winchester, J.A., and Floyd, P.A. 1977. Geochemical discrimination of different magma series and their differentiation products using immobile elements. Chemical Geology, 20, pp. 325-343. http://dx.doi. org/10.1016/0009-2541(77)90057-2

Editorial responsibility: Simon K. Haslett 